\title{
Comparing copepod time-series in the north of Spain: Spatial autocorrelation of community composition
}

\author{
Antonio Bodea, , Maria Teresa Alvarez-Ossorio, Ana Miranda, Angel López-Urrutiac, Luis Valdésc, \\ ${ }^{a}$ Instituto Español de Oceanografía, Centro Oceanográfico de A Coruña, Apdo. 130, 15080 A Coruña, Spain \\ - Instituto Español de Oceanografía, Centro Oceanográfico de Vigo, Apdo. 1552, 36280 Vigo, Spain \\ ' Instituto Español de Oceanografía, Centro Oceanográfico de Gijón, Avda. Príncipe de Asturias $70 b i s, 33212$ \\ Gijón, Spain \\ ${ }^{1}$ Present address: Intergovernmental Oceanographic Commission, UNESCO, Paris, France.
}

*: Corresponding author : A. Bode, email address : antonio.bode@co.ieo.es

\begin{abstract}
:
Four time-series of copepod species biomass in the north of Spain were contrasted to demonstrate spatial autocorrelation of local communities and their responses to short-term local and regional variability in oceanographic conditions. The series represented coastal and oceanic environments along a marked gradient of influence of seasonal upwelling from Galicia to the Mar Cantábrico (S Bay of Biscay), and each one included at least 10 years of continuous data collected at monthly frequency. Community composition (i.e. species number and diversity) was very consistent through the region, but local variations in the presence of new species and the relative proportions of common species allowed for the characterisation of the response to the environment at each site. Small-sized species were more frequent near the coast. A few species, however, captured the main patterns of variability in all series. Calanus helgolandicus and Acartia (mainly Acartia clausi) were generally the main contributors to total biomass, while other species as Paracalanus parvus and Clausocalanus spp. were important only at some locations. Most copepod indices were positively correlated with upwelling, either considering the whole community (biomass, species richness and diversity) or individual species, but only in the coastal series analysed since 1991. Copepods in the nearby ocean, however, showed negative correlations with upwelling in the period 1960-1986. The effects of upwelling may have been modulated by local factors, as showed by the increases in biomass, number of species and diversity in associations with increases in sea surface temperature in Galicia, while in the Mar Cantábrico only the warming-tolerant species increased and those typical of upwelling decreased. Density stratification
\end{abstract}


of the water column was associated to decreases in total copepod biomass in Galicia, while it favoured the increase in species richness in the Mar Cantábrico. Nearly all significant responses of copepods to environmental variability were delayed for up to five months, showing the importance of considering time-lags in the analysis of temporal responses of zooplankton.

\section{Introduction}

Copepods play a key role in pelagic ecosystems, representing $>90 \%$ of total abundance and biomass of mesozooplankton and driving a large part of biogeochemical fluxes relevant for the sustaining of complex food webs and the transfer of carbon to the sediments of continental shelves (Smetacek, 1988). Therefore, planktonic copepod species are generally well known in most seas and form one of the most robust indicators of variability in long-term research programs and time-series (Valdés et al., 2007).

Regional, climate-driven changes in zooplankton were recognized through the Atlantic and mostly related to the warming of the surface waters producing increased stratification in the water column (Beaugrand et al., 2000, 2002; Beaugrand, 2003, 2004; Richardson and Schoeman, 2004, ICES, 2006). Sub-regional and local modulation of the large spatial and temporal trends, however, plays a key role in structuring the communities. Most of the variability in the number of copepod species number and their densities relative to climatic and hydrological forcing was described in plankton from boreal cold water areas, where the stabilization of the water column caused a major modification of the environment (Beaugrand et al., 2000; 2002). Moreover, it seems likely that advective processes play a substantial role and interact with the impact of climate on the hydroclimatic regime. Upwelling-downwelling cycles and shelf currents were pointed out as the main sources of water-mass advection influencing zooplankton communities in the northeastern Atlantic (Beaugrand, 2003). Increases in warm-water species (as Temora stylifera) were attributed both to transport from southern waters and to local warming (Villate et al., 1997; Valdés et al., 2007). Similarly, local increases of copepods in recent years could be explained by a reduction in the offshore transport of surface water during weak upwelling periods (Bode et al., 2009). Such changes are consistent with the overall negative effect of increasing stratification at annual scales (Valdés et al., 2007; Bode et al., 2009).

The northwestern shelf off the Iberian Peninsula offers an unique opportunity to study the variability in copepod communities in a gradient of environmental change. Seasonal upwelling affects the coasts of Portugal and Galicia (northwestern Spain), occasionally extending its influence to the Mar Cantábrico in the southern Bay of Biscay (Botas et al., 1990). In the latter area, the seasonal cycle is characteristic of temperate regions, where the warming of surface water triggers the development of summer stratification and winter cooling is responsible for most of annual mixing 
(Botas et al., 1989; González-Pola et al., 2007). Upwelling, caused primarily by southerly and westerly winds during spring and summer, drives most of the productivity in Galicia (Bode et al., 1996; Alvarez-Salgado et al., 2002), while the spring bloom is the main productivity peak in the Mar Cantábrico (Bode et al., 1996; Llope et al., 2007). Poleward currents, more intense during the autumn-winter transition (Alvarez-Salgado et al., 2003; Varela et al., 2005), also contribute to the along shore transport of water and organisms between Galicia and the Mar Cantábrico (Fernández et al., 1991; Bode et al., 2002). Copepod communities in this area have been studied mainly in connection to seasonal cycles (Alvarez-Ossorio, 1977; Corral and Alvarez-Ossorio, 1978; Valdés et al., 1990; Valdés, 1993; Cabal, 1993), however recent studies focussed on large scale variability related to climate (Villate et al., 1997; Valdés and Moral, 1998; ICES, 2006; Valdés et al., 2007; Bode et al., 2009). Besides hydrographic variability, nutrient inputs and plankton composition and production were well described through this region (e.g. Casas et al., 1997; Llope et al., 2007) thus allowing for a detailed analysis of local versus regional variability.

In this paper we compare time-series of copepod species biomass in the north of Spain with the aim of demonstrating spatial autocorrelation of local communities and their responses to short-term local and regional variability in oceanographic conditions. Copepod species were selected because they were consistently recorded for at least ten years at three coastal sites in the north of Spain (Vigo, A Coruña and Santander). Continuous Plankton Recorder (CPR) data for the same region (Galicia and S Bay of Biscay) were also included to account for variability in the nearby ocean. Temporal trends, periodicity and cross-correlations on the series were analysed, as well as their relationships with temperature, upwelling intensity and water column stratification.

\section{Materials and Methods}

\subsection{Copepod samples}

Copepod species were systematically recorded in the framework of project Radiales (http://www.seriestemporalesieo.net). For this paper, monthly time-series from three sites along the northern coast of Spain were selected (Fig. 1). The series covered at least 10 years of monthly observations and a geographical gradient from the areas of more persistent upwelling conditions (Vigo and A Coruña in Galicia) to more stratified conditions in the southern Bay of Biscay (Santander, Mar Cantábrico). Data from one mid-shelf station (70-110 m depth, Table 1) was selected at each site. In addition, we studied the copepod time-series obtained with the CPR program (http://www.sahfos.org/CPR ) as spatially-integrated mean values for the standard grid F4, representing copepod community composition from the nearby ocean. 
Details of zooplankton sampling procedures of both Radiales and CPR time-series can be found in Valdés et al. (2007) and Richardson et al. (2006), respectively. Briefly, zooplankton from the Radiales series was sampled using 50-cm diameter Juday-Bogorov plankton nets equipped with mesh size $200 \mu \mathrm{m}$ (Vigo, A Coruña) or $250 \mu \mathrm{m}$ (Santander). Tows were double oblique from the surface to $5 \mathrm{~m}$ from the bottom, except in Santander where only the upper $50 \mathrm{~m}$ were sampled. Samples were preserved in 2-4\% sodium borate-buffered formaldehyde. All copepods (Vigo) or at least 1000 copepods per sample (A Coruña and Santander) were counted and classified at genus or species level. Growth stages were recorded separately for most species. Initial values were reported as number of individuals per $\mathrm{m}^{3}$. For CPR series, the self-contained automatic plankton recorder collects plankton continuously from a standard depth of ca. $7 \mathrm{~m}$ (Hays et al., 1995). Samples were collected in a silk net of $270 \mu \mathrm{m}$ mesh size and preserved with formalin. In this paper we used mean abundance values for species recorded in the whole sample (eye count procedure in Richardson et al., 2006) and scaled to numbers per $\mathrm{m}^{3}$ by taking into account that individual CPR samples correspond to approximately 3 $\mathrm{m}^{3}$. To overcome the problem of overrepresentation of species of small body size present in large numbers, all abundance values were transformed to biomass by first scaling mean species body length (e.g. Table 5 of Richardson et al., 2006) to wet-weight (w-w) body biomass (Peters, 1983) and then by multiplying species abundance by speciesspecific body biomass (Richardson et al., 2006). Values for species not included in the Richardson’s et al. study and those from the different growth stages of a given species were calculated from length data obtained from the literature or measurements from actual samples (e.g. Valdés et al., 1990). This procedure allowed for comparison of concurrent but slightly different time-series, because of small local variations in sampling and counting procedures, but it did not intent to provide precise biomass estimates for a given species. A more detailed study of the distribution and variability of actual biomass values of zooplankton species and groups in the study area is available in Valdés et al. (1990). Species and total copepod biomass values were reported as $\mathrm{mg} \mathrm{w}-\mathrm{w} \mathrm{m}^{-3}$.

\subsection{Environmental data}

Sea surface temperature (SST) and upwelling indicators were obtained for each of copepod time-series locations. For CPR F4 series, SST data were monthly averages of all observations available in two $1^{\circ} \mathrm{x} 1^{\circ}$ grids from the International Comprehensive Ocean-Atmosphere Data Set (ICOADS, http://dss.ucar.edu/datasets/), representing the environment conditions of Galicia (grid G in Fig. 1, centred at $42.5^{\circ} \mathrm{N}, 10.5^{\circ} \mathrm{W}$ ) and of Mar Cantábrico (grid C in Fig. 1, centred at $44.5^{\circ} \mathrm{N}, 5.5^{\circ} \mathrm{W}$ ), respectively. Favourable upwelling conditions in these areas were also represented by the alongshore wind speed $\left(\mathrm{m} \mathrm{s}^{-1}\right)$ in each area $\left(-\mathrm{v}_{\mathrm{G}}\right.$ for Galicia and $-\mathrm{u}_{\mathrm{C}}$ for Mar Cantábrico). For the coastal series surface temperature (5 m depth) measurements were obtained from CTD profiles concurrent with copepod sampling at the same stations. In 
addition, stratification of the upper water column at these stations was represented by the $\sigma_{\mathrm{t}}$ increase from 5 to $50 \mathrm{~m}$ measured in the same CTD profiles. The latter parameter was included instead of other measures of stratification, as the standard deviation of temperature in the water column (e.g. Valdés et al., 2007), because of the lack of correlation between temperature and salinity changes in stations from Galicia. Additional information of the environmental variability at the sampling sites can be found in Casas et al. (1997), González-Pola et al. (2007) and Varela et al. (2006).

\subsection{Statistical analyses}

The relationship among copepod time-series was studied by multidimensional scaling (MDS) ordinations. First, BrayCurtis similarity values among observations were computed using biomass values of the dominant ( $>1 \%$ of total biomass in at least one series) copepod species or groups. Values were transformed using the fourth-root transformations (Clarke and Warwick, 2001). Second, samples in the resulting 2-dimensional MDS space were coded according to the time-series to reveal spatial correlations, and the significance of the ordination was studied by examining the averaged rank similarities between and within groups. Third, the most discriminating species and the species characteristic of each series were identified. All these computations were made using the procedures Similarity, MDS, SIMPER and ANOSIM from the PRIMER V. 5 statistical package (Clarke and Warwick, 2001).

Temporal variability of selected variables from each time-series was decomposed in linear, periodic and autocorrelation components using a Box-Jenkins approach (Box and Jenkins, 1976; Nogueira el al., 1998). Each copepod time-series was characterized by the total number of copepod species (S), including also rare species ( $<1 \%$ of total biomass), total copepod biomass (B, mg w/w m-3), copepod diversity (H, Shannon) and the biomass of the three most discriminant species present in all series. Finally, significant variance components $(\mathrm{P}<0.05)$ were removed before cross-correlation analysis with similarly treated environmental variables. The significance of linear (trend) components, including autocorrelation was assessed using ANOVA tests, while the significance of periodic components was determined using the Fisher-G statistic (Swan and Sandilanks, 1995). Box-Jenkins analysis were made using MATLAB (Component Run Time version 7.7).

\section{Results}

\subsection{Species richness and biomass}

A total of 79 copepod categories (excluding eggs and copepodites but including nauplii) were recorded. Full lists of these categories can be consulted in Richardson et al. (2006) and Valdés et al. (2007). Only 16 copepod categories were simultaneously observed at all series. The number of categories recorded was lower for the CPR series (36 categories) 
than for the Radiales series (63, 44 and 39 for A Coruña, Vigo and Santander, respectively). To compare the series, 25 representative categories having $>1 \%$ of total biomass recorded in at least one series were selected (Table 2). Categories with $<1 \%$ of total biomass were grouped as other copepoda.

Calanus helgolandicus, mainly young stages, and Acartia species, mainly A. clausi, showed the largest biomass values in almost all series, representing on average between 17 and 30\% of total copepod biomass (Table 2). In addition, other species showed biomass contributions near $10 \%$, but these secondary species were characteristic of each series. For instance, Centropages typicus amounted on average 8\% of total biomass in the CPR series, while in Vigo Centropages chierchiae and Pseudocalanus elongatus had similar contributions. In A Coruña species contributions were more balanced, with Oncaea media as secondary species (13\% of biomass). In Santander, Paracalanus parvus (14\%) and Dytrichocorycaeus anglicus (11\%) were the species contributing most to total biomass after C. helgolandicus, with average values even higher than $A$. clausi (9\%). The remaining species were much less abundant, with occasional biomass peaks but in general with contributions to total biomass lower than $5 \%$.

\subsection{Spatial ordination of series}

The MDS ordination of all copepod series reflected their geographic origin (Fig. 2). The largest variability was exhibited by the CPR series, as the data covered a longer time period and spatial domain than the other series, while the data from coastal series appeared far more grouped with large overlapping for Galicia series (Vigo and A Coruña). Interestingly, a second MDS considering only the coastal series and also showing the large similarity between Vigo and A Coruña, clearly allowed the separation of the observations from the Galicia series from those of Santander in the Mar Cantábrico. The obtained ordinations were acceptable, as the stress values of both MDS plots were close to 0.2 (Clarke and Warwick, 2001). For the initial ordination with all series, the value of the R statistic comparing the similarity between and within series was significant $(\mathrm{R}=0.383, \mathrm{P}<0.001)$, indicating that, on average, the observations within each series were more similar to one another than observations from other series (Clarke and Warwick, 2001). Pairwise comparisons of R between series also produced significant values (Fig. 3).

As the original biomass data were transformed to avoid the large contribution of dominant species in terms of abundance, the separation among series was due to less abundant but characteristic species, with average contributions to dissimilarity $<10 \%$ (Fig. 3). Paracalanus parvus, Oithona plumifera and O. media were the main species discriminating CPR samples from those of coastal series, as these species were not present in the former (Table 2). Juvenile stages of $C$. helgolandicus were not recorded separately in Santander series and contributed to a large percentage of dissimilarity among coastal series, suggesting an overestimation of the biomass of this species in 
Santander. The separation of Santander series from those of Galicia, however, was due not only to C. helgolandicus but also to changes in other species. For instance, Clausocalanus spp. was present in all series but reached high biomass contributions in Santander and very low ones in Vigo. Further separation was due to Paraeuchaeta hebes, for Galicia series, and Eucalanus elongatus, for A Coruña and Santander series (Fig. 3).

As we mentioned before for the analysis of the average biomass (Table2), A. clausi and C. helgolandicus were the species with the largest contribution to within series similarity for CPR and Vigo series (Table 3). A. clausi also showed the largest contribution to similarity in A Coruña, followed by P. parvus, while the contribution of $C$. helgolandicus was relatively low. In Santander, $P$. parvus and Clausocalanus spp. showed the largest contributions to similarity.

\subsection{Temporal variability}

Univariate measures revealed also differences among series that can be attributed to both their spatial separation but also to the time period covered by each series (Table 4). Mean values of the number of copepod species or categories (S) and total biomass (B) were much lower for CPR series, even considering the two periods with continuous data, than for coastal series. These differences can be explained by the location of samples of the CPR series, generally obtained near the surface and far from the coast, while those of coastal series were depth-integrated. Diversity values, however, were more similar among series, indicating an equivalent structure of the copepod community at all sites. Analysing time components of the series, a few series showed significant linear trends with time (Table 4). Only the number of species and diversity increased significantly in the CPR series during the period 1960-1986, while an opposite pattern occurred at A Coruña between 1994 and 2006. Periodic components were only significant in the case of biomass and only for some of the series, indicating the recurrent effect of annual seasons on copepods. Seasonal plots of these values showed that the increase of species recorded in the CPR was concentrated mainly in the spring and autumn, even in the most recent period (Fig. 4). Similarly, the largest decrease in species and diversity at A Coruña occurred also in these seasons. Biomass changes, although with non significant linear trends, were also apparent in some series. For instance, maximum annual values decreased in the CPR series, while autumn values increased in Vigo. The series of Santander did not show significant year-to-year changes, however the seasonal pattern of univariate measures revealed that the number of species and diversity were characteristically high during summer. In contrast, the series from Galicia showed a more irregular distribution of high and low species and diversity values. Autocorrelation between adjacent monthly samples was significant for the number of species (Table 4). Nevertheless, there was no significant autocorrelation even at up to six month lag for any of the univariate measures analysed. 
The biomass values of the main copepod species did not had significant linear trends with time, except for Clausocalanus spp. from A Coruña and C. helgolandicus from Santander that showed decreasing biomass with time (Table 4). C. helgolandicus juveniles and adults, considered as separate categories for the similarity analyses above, were now combined into a single category for the time-series analysis. Significant seasonality was also shown by $C$. helgolandicus and A. clausi in A Coruña, and by the latter species also in Santander, while there were no significant periodic components for the main species in the remaining series (Vigo and CPR). Such seasonality was the consequence of the concentration of annual maximum biomass values between March and October in both species. In contrast, autocorrelation at one month lag was significant for at least one species in each series. In this way, A. clausi displayed significant autocorrelation in all series except in Vigo and in CPR during the period 1960-1986. Similarly, Clausocalanus spp. biomass was autocorrelated in Vigo and C. helgolandicus in Santander (Table 4). Although no significant trends were observed a decrease in the maximum biomass values can be distinguished in the seasonal distribution of values between the two continuous periods in CPR series (Fig. 5). Similarly, high biomass values of $A$. clausi and C. helgolandicus (but not Clausocalanus spp.) were more frequent in recent years in Vigo while this increase was not apparent for A Coruña.

\subsection{Relationships with local and regional factors}

Environmental conditions varied characteristically among sampling areas (Fig. 6). Surface temperature had both the largest values and annual variance in the Mar Cantábrico whereas it had low values and variance in Galicia. Conversely, upwelling favourable winds (positive values of both $-\mathrm{v}_{\mathrm{G}}$ and $-\mathrm{u}_{\mathrm{C}}$ ) were faster and more frequent in the latter than in the former region. Despite the higher importance of upwelling and associated colder and well-mixed waters in Galicia, likely due to the vicinity of the rias and inputs of freshwater, the stratification of the upper $50 \mathrm{~m}$ of the water column was on average higher in the series of Vigo than in other coastal sites. Seasonality was evident in the series of environmental variables, particularly those of temperature, accounting for up to $90 \%$ of total variance. In contrast, there were no significant linear trends in monthly mean values.

Cross-correlation among prewhitened residuals of copepod and environmental variables was significant at zero lag for a few cases, suggesting that most effects of environmental changes on copepods were delayed for one or several months (Table 5). The sign of the correlations, however, varied among series as local conditions alter the influence of the different factors on copepods. For instance, upwelling conditions were negatively correlated with copepod diversity, biomass and C. helgolandicus with a delay from 2 to 4 months for the CPR series, and with the number of species in A Coruña. In Vigo and A Coruña, however, the effect of upwelling was positive on total biomass and that of A. clausi and 
C. helgolandicus measured 3 to 5 months later. Upwelling in the Mar Cantábrico was also related to 3 to 5 month delayed increases in biomass and diversity at Santander, as well as increases of A. clausi and decreases of $C$. helgolandicus in the most recent CPR series period.

The effects of temperature were generally positive on copepods with 1 to 4 month-lags, as found with total biomass, number of species and diversity in the CPR and Galicia series (Table 5). For Santander, high temperature values were related to concurrent high biomass of $C$. helgolandicus and Clausocalanus but also to decreases in A. clausi one moth later. Stratification was negatively correlated with biomass in Vigo and A Coruña at lags of up to 4 months. In contrast, stratification showed positive correlations with Clausocalanus spp. at 3 month-lags in A Coruña, and with the number of copepod species and the biomass of C. helgolandicus at one month-lag in Santander.

\section{Discussion}

\subsection{Spatial continuity of copepod communities}

The copepod community in the southern Bay of Biscay, including also waters of Galicia, has a transitional character due to the presence of species characteristic of the nearby regions (Valdés et al., 2007). Our results support earlier studies based on presence/absence or abundance data concluding the general homogeneity of species assemblages in this region (Valdés et al., 1990; Cabal, 1993; Valdés, 1993), with local variations mainly related to rias, estuaries and coastal habitats (e.g. Alvarez-Ossorio, 1977; Corral and Alvarez-Ossorio, 1978; Villate et al., 1997; Bode et al., 2005). Valdés (1993) identified three main assemblages in this region: (I) species of general distribution, corresponding to the type “shared” (Darlington, 1957) or "intermediate” species (Colebrook et al., 1961); (II) neritic-oceanic species, and (III) species from rias and estuaries. The two last groups include the "transitional" species (Darlington, 1957) that are dominant in a particular region but extend to nearby regions. Species of general distribution include those most discriminant and characteristically varying among time-series, as C. helgolandicus, A. clausi, P. parvus and Clausocalanus spp. The group also includes indicator species, generally not the ones with maximum abundance, but typical of waters from boreal or subtropical areas (Corral and Alvarez-Ossorio, 1978;Valdés et al., 1990). T. stylifera is an example of warm water species progressively expanding into the region in recent years (Villate et al., 1997; Valdés et al., 2007; Bode et al., 2009). Because of the relatively narrow shelf and the highly dynamic environment caused by the upwelling and water-mass advections in this region, most species belong to the neritic-oceanic group. Their dominance, however, is generally lower than that of species in the first group, as evidenced in the average biomass contributions of most species (Table 2). 
Despite the variations in sampling sites, methods, counting procedures, and the different length of the observational periods, all time-series analysed in this study revealed the high coherence of the copepod community in the number of species, diversity and dominant species. A detailed discussion on the difficulties found when comparing zooplankton time-series can be found in Valdés et al. (2007). Spatial differences, however, explain the ordination of the observations in the MDS analysis, which closely resembles the actual geographical origin of each series (Fig. 2). Distance to the coast is likely the main factor implied in the separation of CPR from coastal series, as found in studies considering across-shelf distributions (Valdés, 1993; Cabal, 1993; Valdés and Moral, 1998). Habitat preferences of some species also contribute to the characterisation of the series, as it occurs with the oceanic C. typicus vs. the neritic C. chierchiae (Bonnet et al., 2007). In contrast, offshore export of coastal species by upwelling may contribute to the homogeneity in the composition, as suggested by the relatively high dominance of Acartia spp. in both oceanic and coastal series. Relatively large differences between CPR and Santander series can be explained because most samples for the F4 grid in the former came actually from the western side of the grid (Richardson et al., 2006). The largest difference was found between Vigo and Santander series, the end-members of the upwelling-stratification geographic gradient. Strong coherence in the composition of zooplankton was also found in other studies comparing long time-series from the same region (Beaugrand et al., 2002; Lavaniegos and Ohman, 2007).

Several statistical methods could have been employed as an alternative to MDS to show the spatial ordination of the time-series in this study. Cluster analysis, for instance, was chosen to show the biogeographical associations of copepod species in this NE Atlantic region using available check lists (Cabal, 1993; Valdés, 1993; Valdés et al., 2007). While the cluster ordinations fitted well with the expected relationships and were well suited to compare data obtained by different procedures (even semi-quantitative or presence-absence data), the results of cluster analysis were largely dependent on the statistical decisions taken during the analysis. Therefore, the type of transformation applied to raw data, the similarity or dissimilarity index, along with the grouping method, produce very different ordinations (Clarke and Warwick, 2001). Even for quantitative data, the large differences in the abundance of species of small individual body size require data transformations aimed at the reduction of excessive weight of the most abundant species. Factorial analyses have also been employed in the analysis of zooplankton series, but in this case the objectives were generally related to the identification of the main species characterizing the series or as a reference space for projection of environmental factors influencing copepod species. Valdés (1993) employed correspondence analysis to identify the spatial and temporal structure of zooplankton samples from A Coruña and to infer the underlying oceanographic factors affecting their distribution. Similarly, Cabal (1993) applied principal component analysis to copepod abundance records in the Mar Cantábrico to the identification of the main patterns of variability across the shelf and through the seasonal 
succession. Further application of factorial analysis was the use of three-mode principal components analysis to address simultaneously spatial, temporal and species variability in plankton time-series (Beaugrand et al., 2000). Factorial analysis, however, have relatively strong restrictions in their application to biological counts, as normality, homoscedascity and proportionality between the number of variables and observations (Digby and Kempton, 1987). In contrast, MDS ordination, even when it is also dependent on the data transformations and similarity measures chosen, it makes few assumptions about the distribution of the data or the inter-relationship of the observations, and its rationale is the preservation of these relationships in the low-dimensional ordination space (Clarke and Warwick, 2001). The resulting ordination retains fundamental characteristics of the original data, as shown by the correspondence between the observations plotted in Fig. 2 and their geographical location in Fig. 1. In addition, the use of biomass data in our study allowed for an ordination of species related to their actual contribution to biomass and fluxes in the pelagic food web.

\subsection{Regional vs. local variability}

Previous studies in this region showed that seasonality was one main source of variability in copepod abundance (Valdés, 1993; Cabal, 1993, Valdés and Moral, 1998; Valdés et al., 2007). Our results also point to the importance of seasonal variability but mainly in the biomass of main species and total biomass, reaching up to $30 \%$ of total variance. Even in this case, significance of seasonality was more common in copepod series from the north and east of the study area (A Coruña and Santander) than in the eastern and south series (Vigo and CPR). These results reflect the important role of the upwelling in the west of the area, disturbing the expected seasonal cycle imposed by the thermal stratification of the water column, as described for the Mar Cantábrico (Cabal, 1993; Villate et al., 1997; Valdés and Moral, 1998). In contrast, diversity and species richness did not show significant seasonality in any of the series, suggesting that copepod species assemblages were approximately constant through the region. Changes in diversity were therefore related to the annual succession and to the disturbance introduced by occasional upwelling events (Valdés, 1993).

Local variability in the patterns of water column stratification was the main differential factor among series. Previous studies also noted the different patterns of thermal stratification in the coastal series of this region (Valdés and Moral, 1998; Valdés et al., 2007). The use of $\sigma_{t}$ differences instead of the variability in the vertical profiles of temperature in this study, however, allowed for a better characterization of the water column of all series, as in those from Galicia salinity variability due to the influence of nearby rias and runoff was larger than in the Mar Cantábrico (Varela et al., 2005), where thermal stratification prevailed (Botas et al., 1989; González-Pola et al., 2007). For instance, copepods 
from Galicia are exposed to larger variability in stratification than those from the Mar Cantábrico. Stratification largely controls the input of nutrients into the upper photic layers and thus influences the structure and function of pelagic food webs. The intensity and duration of the stratification phase is expected to increase as a result or global warming (Roemmich and McGowan, 1995; Sarmiento et al., 2004), as observed in the Mar Cantábrico (Valdés et al., 2007). Decreasing upwelling intensity and frequency off the western Iberian peninsula in the last $40 \mathrm{y}$ (Lemos and Sanso, 2006; Alvarez et al., 2008) may have contributed to enhance stratification but the observed series in Galicia did not show significant year-to-year variability. Changes in the salinity of upwelled waters (Pérez et al., 2000) and the influence of freshwater along the coast (Varela et al., 2005), however, ensure a large variability of stratification in Galicia. Our results confirm that the higher biomass and abundance of the main species in Galicia compared to those in the Mar Cantábrico series are related to the frequent disturbance introduced by upwelling and other events affecting stratification (Valdés, 1993; Valdés et al., 2007; Bode et al., 2009), even during a multidecadal period of decreasing upwelling. However, the effect appears to depend largely on the frequency of the disturbance (as increasing density gradients significantly decreased copepod biomass in Galicia but not in Santander; Table 5) rather than on the mean value of the stratification measure chosen (as found with the standard deviation of temperature in Valdés et al., 2007).

Our comparative analysis of the series at intraseasonal time scales reveals a general coincidence in the environmental forcing factors identified with those of annual scale studies in this region (Beaugrand et al., 2000; 2002; Valdés et al., 2007; Bode et al., 2009). Warming of the surface waters allows for increasing dominance of some species (as $T$. stylifera) and contributes for substantial modifications in the stability of the water column, particularly in the Bay of Biscay. The upwelling and outflow from the rias in Galicia, however, modifies the direct influence warming and the environmental fluctuations are mostly absorbed at annual scales (Bode et al., 2009). Therefore, temperature is generally more influential on copepod communities in Santander than in Galicia, where upwelling intensity is the variable with more significant cross-correlations (Table 5). Upwelling is also of marginal importance in the ocean, as shown by CPR series. Nevertheless, large offshore advection could have been the cause of the decrease in diversity and total and $C$. helgolandicus biomass in the period 1960-1986, characterised by the highest intensity and frequency of upwelling (Lemos and Sanso, 2006). Furthermore, our analysis shows that the responses of zooplankton to environmental forcing were lagged for several months. The delay between environmental change and changes in the community is indicative of non-linear interactions, likely amplified through the food web (Duarte et al., 1990).

The different responses of the main copepod species to the environment can be related to their niche preferences. For instance, the biomass of Clausocalanus spp. showed a positive relationship with warming and stratification of surface waters in all coastal locations, as was noted in previous studies in a larger north Atlantic region (Beaugrand et al., 
2002). In contrast, A. clausi was more influenced by the intensity of upwelling and the presence of cold waters in the surface, as this species is typical of upwelling-influenced, coastal sites in the southern Bay of Biscay (Alvarez-Ossorio, 1977; Corral and Alvarez-Ossorio, 1978; Valdés, 1993) but less dominant towards the west of the region, in the Mar Cantábrico area (Villate et al., 1997; Valdés and Moral, 1998). Other species, however, showed different links to environmental variables in Galicia compared to the Mar Cantábrico. For instance, C. helgolandicus showed a good correspondence with increasing surface temperature at various time scales in the Mar Cantábrico, as noted in previous studies (Cabal, 1993; Villate et al., 1997; Valdés and Moral, 1998), while it was positively related to cold waters and upwelling in Galicia. According to recent reviews (Bonnet et al., 2005) this species is generally found in waters with a range of temperature from $9-20^{\circ} \mathrm{C}$, with maximum abundances from $13-17^{\circ} \mathrm{C}$. Therefore, water column conditions in Galicia are within the optimal range for this species, whereas increasing warm-up of waters in the Mar Cantábrico may drive it towards northern and colder areas.

\section{Conclusions}

Despite the marked transitional character imposed by the seasonal upwelling in the coast and nearby ocean of northwestern Spain, the composition of copepod community is fairly consistent in this region. Species richness and diversity in the analysed series vary within relatively narrow limits, even taking into account that some of the series extend over more than 40 years. Structural differences, however, characterize each location. For instance, samples from the nearby ocean show the largest variability because this series includes larger spatial and temporal scales than the coastal ones, but also to the lack of copepod species of small body size as P. parvus, O. plumifera and O. media. Near the coast, differences in the relative contributions to biomass by several dominant species explain most of the local variability. Acartia species (mainly A. clausi) and C. helgolandicus are the species reaching highest average abundance at almost all sites, but P. parvus contributes to the local differentiation of A Coruña series and Clausocalanus spp. to that of Santander.

Year-to-year changes are largely dependent on the location and the period analysed. The number of copepod species, Clausocalanus spp. and total biomass has been decreasing in A Coruña since 1994. Calanus helgolandicus also decreased in Santander between 1991 and 2001. In Vigo, however, A. clausi and C. helgolandicus increased recently, and the CPR series showed an increasing trend of biomass and species number in the period 1960-1986. For all series, total copepod biomass follows the characteristic seasonal pattern related to the cycles of upwelling and local oceanographic conditions, but seasonality in species cycles is more variable. The effect of regional (upwelling) factors is modulated by local conditions (surface temperature and stratification) and significant lags in the response of 
copepods occur at the intraseasonal scale (1 to 5 months). Upwelling can be associated to increases in copepod biomass and diversity near the coast, particularly in A Coruña and Santander but decreases diversity, species richness and $C$. helgolandicus in the nearby ocean. Warming of the surface waters also allows high biomass, diversity and species numbers in the area of large influence of upwelling (Galicia) while in Santander it causes an immediate increase in warm-tolerant species as Clausocalanus spp. and C. helgolandicus and a decrease in species related to cold, upwelling waters, as A. clausi. These results highlight the importance of local factors in the response of plankton communities to large scale variability in environmental conditions. Therefore, a few indicator species may be used to characterise community changes at both local and regional scales as a result of environmental and climatic variability.

\section{Acknowledgements}

We are grateful to all scientists and technicians involved in plankton data collection and sustaining the time-series employed in this study. D. Johns (SAHFOS) kindly provided the grid-averaged data from the CPR survey. G. GonzálezNuevo and E. Nogueira (IEO, Centro Oceanográfico de Gijón) made available the software for the time-series analysis. This research was funded in part by projects Radiales (IEO) and REFORZA (PGIDIT06RMA60401PR) of the Galician Government (Xunta de Galicia).

\section{References}

Alvarez, I., Gómez-Gesteira, M., De Castro, M., Dias, J.M., 2008. Spatiotemporal evolution of upwelling regime along the western coast of the Iberian Peninsula. Journal of Geophysical Research 113(C07020), doi:10.1029/2008JC004744.

Alvarez-Ossorio, M.T., 1977. Un estudio de la comunidad de copépodos de la Ría de Muros en noviembre de 1975. Boletín del Instituto Español de Oceanografía 233, 75-108.

Alvarez-Salgado, X.A., Beloso, S., Joint, I., Nogueira, E., Chou, L., Pérez, F.F., Groom, S., Cabanas, J.M., Rees, A.P., Elskens, M., 2002. New production of the NW Iberian shelf during the upwelling season over the period 19821999. Deep Sea Research 49, 1725-1739.

Alvarez-Salgado, X.A., Figueiras, F.G., Pérez, F.F., Groom, S., Nogueira, E., Borges, A.V., Chou, L., Castro, C.G., Moncoiffé, G., Ríos, A.F., Miller, A.E.J., Frankignoulle, M., Savidge, G., Wollast, R., 2003. The Portugal coastal counter current off NW Spain: new insights on its biogeochemical variability. Progress in Oceanography 56, 281321.

Beaugrand, G., 2003. Long-term changes in copepod abundance and diversity in the northeast Atlantic in relation to fluctuations in the hydroclimatic environment. Fisheries Oceanography 12, 270-283. 
Beaugrand, G., 2004. The North Sea regime shift: evidence, causes, mechanisms and consequences. Progress in Oceanography 60, 245-262.

Beaugrand, G., Ibanez, F., Reid, P.C., 2000. Spatial, seasonal and long-term fluctuations of plankton in relation to hydroclimatic features in the English Channel, Celtic Sea and Bay of Biscay. Marine Ecology Progress Series 200, 93-102.

Beaugrand, G., Reid, P.C., Ibañez, F., Lindley, J.A., Edwards, M., 2002. Reorganization of North Atlantic Marine Copepod Biodiversity and Climate. Science 296, 1692-1694.

Bode, A., Varela, M., Casas, B., González , N., 2002. Intrusions of eastern North Atlantic central waters and phytoplankton in the north and northwestern Iberian shelf during spring. Journal of Marine Systems 36, 197-218.

Bode, A., Alvarez-Ossorio, M.T., Cabanas, J.M., Miranda, A., Varela, M., 2009. Recent trends in plankton and upwelling intensity off Galicia (NW Spain). Progress in Oceanography 83, 342-350.

Bode, A., Casas, B., Fernández, E., Marañón, E., Serret, P., Varela, M., 1996. Phytoplankton biomass and production in shelf waters off NW Spain: spatial and seasonal variability in relation to upwelling. Hydrobiologia 341, 225-234.

Bode, A., Alvarez-Ossorio, M.T., González, N., Lorenzo, J., Rodríguez, C., Varela, M., Varela, M.M., 2005. Seasonal variability of plankton blooms in the Ria de Ferrol (NW Spain): II. Plankton abundance, composition and biomass. Estuarine, Coastal and Shelf Science 63, 285-300.

Bonnet, D., Harris, R., López-Urrutia, A., Halsband-Lenk , C., Greve , W., Valdés, L., Hirche, H.-J., Engel, M., Alvarez-Ossorio, M.T. \& Wiltshire, K., 2007. Comparative seasonal dynamics of Centropages typicus at seven coastal monitoring stations in the North Sea, English Channel and Bay of Biscay. Progress in Oceanography 72, 233-248.

Bonnet, D., Richardson, A., Harris, R., Hirst, A.B., G., Edwards, M., Ceballos, S., Diekman, R., Lopez-Urrutia, A., Valdes, L., Carlotti, F., Molinero, J.C., Weikert, H., Greve, W., Lucic, D., Albaina, A., Yahia, N.D., Umani, S.F., Miranda, A., dos Santos, A., Cook, K., Robinson, S., de Puelles, M.L.F., 2005. An overview of Calanus helgolandicus ecology in European waters. Progress in Oceanography 65, 1-53.

Botas, J., Fernández, E., Bode, A., Anadón, R., 1989. Water masses off Central Cantabrian Coast. Scientia Marina 53, 755-761.

Botas, J.A., Fernández, E., Bode, A., Anadón, R., 1990. A Persistent Upwelling off the Central Cantabrian Coast (Bay of Biscay). Estuarine, Coastal and Shelf Science 30, 185-199.

Box, G.E.P., Jenkins, G.M., 1976. Time-series Analysis: Forecasting and Control. Ed. Holden-Day, San Francisco, 575 pp. 
Cabal, J.A., 1993. Estructura y dinámica de las poblaciones de copépodos planctónicos en la costa central de Asturias. PhD Thesis, Universidad de Oviedo, Oviedo, 349 pp.

Casas, B., Varela, M., Canle, M., González, N., Bode, A., 1997. Seasonal variations of nutrients, seston and phytoplankton, and upwelling intensity off La Coruña (NW Spain). Estuarine, Coastal and Shelf Science 44, 767778.

Clarke, K.R., Warwick, R.M., 2001. Change in marine communities: An approach to statistical analysis and interpretation. PRIMER-E Ltd., Plymouth (UK), 171 pp.

Corral, J., Alvarez-Ossorio, M.T., 1978. El zooplancton de la Ria de Arosa I. Composición y distribución de las comunidades en un ciclo anual. Boletín del Instituto Español de Oceanografía 265, 133-136.

Colebrook, J.M., Glover, R.S., Robinson, G.A., 1961. Continuous plankton records: Contribution towards a plankton atlas of the north-eastern Atlantic and the North Sea. Bulletin of Marine Ecology 5(42), 67-80.

Darlington, P.J., 1957. Zoogeography: the geographical distribution of animals. J. Wiley and Sons, New York, 675 pp.

Digby, P.G.N., Krempton, R.A., 1987. Multivariate analysis of ecological communities. Chapman \& Hall, London, 206 pp.

Duarte, C., 1990. Time lags in algal growth: generality, causes and consequences. Journal of Plankton Research 12, 873-883.

Fernández, E., Bode, A., Botas, A., Anadón, R., 1991. Microplankton assemblages associated with saline fronts during a spring bloom in the Central Cantabrian Sea: differences in trophic structure between water bodies. Journal of Plankton Research 13, 1239-1256.

González-Pola, C., Fernández-Díaz, J.M., Lavín, A., 2007. Vertical structure of the upper ocean from profiles fitted to physically-consistent functional forms. Deep Sea Research 54, 1985-2004.

Hays, G. C., Warner, A. J., John, A. W. G., Harbour, D. S., \& Holligan, P. M. (1995). Coccolithophores and the continuous plankton recorder survey. Journal of the .Marine Biological Association of the United Kingdom 75, 503-506.

ICES, 2006. Zooplankton monitoring results in the ICES area: Summary status report 2004/2005. ICES Cooperative Research Report 281, 1-43.

Lavaniegos, B.E., Ohman, M.D., 2007. Coherence of long-term variations of zooplankton in two sectors of the California Current System. Progress in Oceanography 75, 42-69.

Lemos, R.T., Sanso, B., 2006. Spatio-temporal variability of ocean temperature in the Portugal Current System. Journal of Geophysical Research 111, doi:10.1029/2005JC003051. 
Llope, M., Anadón, R., Sostres, J.A., Viesca, L., 2007. Nutrients dynamics in the southern Bay of Biscay (1993-2003): Winter supply, stoichiometry, long-term trends, and their effects on the phytoplankton community. Journal of Geophysical Research 112, doi:10.1029/2006JC003573.

Nogueira, E., Perez, F.F., Rios, A.F., 1998. Modelling nutrients and chlorophyll a time-series in an estuarine upwelling ecosystem (Ria de Vigo: NW Spain) using the Box-Jenkins approach. Estuarine, Coastal and Shelf Science 46, 267-286.

Pérez, F.F., Pollard, R.T., Read, J.F., Valencia, V., Cabanas, J.M., Ríos, A.F., 2000. Climatological coupling of the thermohaline decadal changes in Central Water of the Eastern North Atlantic. Scientia Marina 64, 347-353.

Peters, R.H., 1983. The ecological implications of body size. Cambridge University Press, Cambridge, 329 pp.

Richardson, A.J., Schoeman, D.S., 2004. Climate impact on plankton ecosystems in the Norteast Atlantic. Science 305, 1609-1612.

Richardson, A.J., Walne, A.W., John, A.W.G., Jonas, T.D., Lindley, J.A., Sims, D.W., Stevens, D., Witt, M., 2006. Using continuous plankton recorder data. Progress in Oceanography 68, 27-74.

Roemmich, D., McGowan, J., 1995. Climatic warming and the decline of zooplankton in the California Current. Science 267, 1324-1326.

Sarmiento, J.L., Slater, R., Barber, R., Bopp, L., Doney, S.C., Hirst, A.C., Kleypas, J., Matear, R., Mikolajewicz, U., Monfray, P., Soldatov, V., Spall, S.A., Stouffer, R., 2004. Response of ocean ecosystems to climate warming. Global Biogeochemical Cycles 18, doi:10.1029/2003GB002134

Smetacek, V., 1988. Plankton characteristics. In: Postma, H.,Zijlstra, J.J. (Editors), Continental Shelves. Elsevier, N York, pp. 93-130.

Swan, A.R.H., Sandilands, M., 1995. Introduction to geological data analysis. Blackwell Science Ltd., London, 431 pp.

Valdés, L., 1993. Composición, abundancia y distribución del mesozooplancton en la plataforma continental frente a La Coruña. PhD. Thesis, Universidad de Oviedo, Oviedo, 245 pp.

Valdés, L., Moral, M., 1998. Time-series analysis of copepod diversity and species richness in southern Bay of Biscay off Santander, Spain, in relation to environmental conditions. ICES Journal of Marine Science 55, 783-792.

Valdés, L., Alvarez-Ossorio, M.T., Varela, M., 1990. Relación entre la estructura de tallas y la biomasa del zooplancton nerítico en la plataforma de La Coruña (NO de España). Boletín del Instituto Español de Oceanografía 6, 97-106.

Valdés, L., López-Urrutia, A., Cabal, J., Alvarez-Ossorio, M., Bode, A., Miranda, A., Cabanas, M., Huskin, I., Anadón, R., Alvarez-Marqués, F., Llope, M., Rodríguez, N., 2007. A decade of sampling in the Bay of Biscay: What are the zooplankton time-series telling us? Progress in Oceanography 74, 98-114. 
1 Varela, M., Bode, A., Lorenzo, J., Alvarez -Ossorio, M.T., Miranda, A., Patrocinio, T., Anadón, R., Viesca, L., Rodríguez, N., Valdés, L., Cabal, J., Urrutia, A., García-Soto, C., Rodríguez, M., Alvarez-Salgado, X.A., Groom, S., 2006. The effect of the 'Prestige' oil spill on the plankton in the N-NW Spanish coast. Marine Pollution Bulletin 53, 272-286.

5 Varela, R.A., Rosón, G., Herrera, J.L., Torres-López, S., Fernández-Romero, A., 2005. A general view of the hydrographic and dynamical patterns of the Rías Baixas adjacent sea area. Journal of Marine Systems 54, 97-113. Villate, F., Moral, M., Valencia, V., 1997. Mesozooplankton community indicates climate changes in a shelf area of the inner Bay of Biscay throughout 1988 to 1990. Journal of Plankton Research 19, 1617-1636. 


\section{Figure captions}

2 Figure 1. Map of sampling sites of copepod time-series. Continuous Plankton Recorder (CPR) series are from the

3 standard grid area F4. Shaded areas in the upper map indicate the location of $1^{\circ} \mathrm{x} 1^{\circ}$ grids from where monthly averaged

4 ICOADS temperature and wind data were recovered in Galicia (G) and Mar Cantábrico (C) regions.

5 Figure 2. Multidimensional scaling (MDS) plots of all (a) or coastal (b) copepod time-series observations from a

6 similarity matrix using the Bray-Curtis coefficient computed from fourth-root transformed biomass values. Series

7 names as in Table 1 . Separate MDS analyses were made for each plot.

8 Figure 3. Differences among copepod time-series. The numbers along the arrows are values of R-statistic indicating the

9 magnitude of the averaged, rank Bray-Curtis similarity values among series compared to those averaged within series

10 (Clarke and Warwick, 2001). The global R considering all series is 0.383 . All $\mathrm{R}$ values were significant with $\mathrm{P}<0.001$.

11 The species most contributing to dissimilarity among series, along with the percentage of dissimilarity accounted for, 12 are also indicated. Series names as in Table 1.

13 Figure 4. Variability of number of copepod species (S), biomass (B, mg w/w $\mathrm{m}^{-3}$ ) and diversity (H, bits indiv. $\left.{ }^{-1}\right)$ in the studied time-series.

Figure 5. Variability of biomass (mg w/w $\mathrm{m}^{-3}$ ) of selected copepod species in the studied time-series. Mar Cantábrico areas $\left(-\mathrm{u}_{\mathrm{C}}\right)$, and stratification $\left(\Delta \sigma_{\mathrm{t}}\right)$ in the studied time-series. 
1 Table 1.

2 Characteristics of copepod time-series employed in this study.

\begin{tabular}{llcccrrrr}
\hline \multicolumn{1}{c}{ Series } & \multicolumn{1}{c}{ Site } & Station & Latitude N & Longitude W & Depth & Start date & End date & N \\
\hline CPRF4 & grid F4 & --- & --- & --- & 7 & Apr-1958 & Dec-2006 & $365^{\text {a }}$ \\
VIE3 & Vigo & E3 & $4^{\circ}$ 08.50' & $8^{\circ}$ 57.50' & 97 & Jan-1994 & May-2006 & 134 \\
COE2 & A Coruña & E2 & $4^{\circ}$ 25.30' & $8^{\circ}$ 26.20' & 77 & Jan-1994 & Dec-2006 & 144 \\
SAE4 & Santander & E4 & $4^{\circ} 34.40^{\prime}$ & $3^{\circ}$ 47.00' & 110 & Jun-1991 & Jan-2001 & 121 \\
\hline
\end{tabular}

3

$4 \quad \mathrm{~N}$ : number of observations.

$5 \quad{ }^{a}$ large gaps in the series between 1987 and 1997 
Table 2.

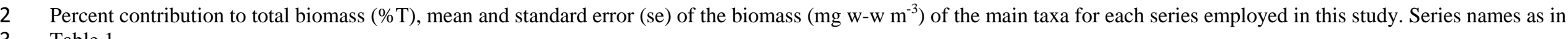
3 Table 1.

\begin{tabular}{|c|c|c|c|c|c|c|c|c|c|c|c|c|}
\hline \multirow[b]{2}{*}{ Category } & \multicolumn{3}{|c|}{ CPRF4 } & \multicolumn{3}{|c|}{ VIE3 } & \multicolumn{3}{|c|}{ COE2 } & \multicolumn{3}{|c|}{ SAE4 } \\
\hline & $\% \mathrm{~T}$ & mean & se & $\% \mathrm{~T}$ & mean & se & $\% \mathrm{~T}$ & mean & se & $\% \mathrm{~T}$ & mean & se \\
\hline 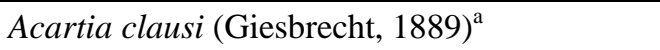 & 35.82 & 7.45 & 0.71 & 22.86 & 86.54 & 26.39 & 16.51 & 46.65 & 4.71 & 8.87 & 11.76 & 1.77 \\
\hline Calanoides carinatus (Kröyer, 1848) & 1.49 & 0.31 & 0.05 & 2.51 & 9.50 & 1.57 & 3.37 & 9.51 & 1.72 & 6.31 & 8.36 & 2.44 \\
\hline Calanus helgolandicus (I-IV) (Claus, 1863) & 15.50 & 3.22 & 0.68 & 28.50 & 107.88 & 56.12 & 6.24 & 17.63 & 2.64 & --- & --- & --- \\
\hline Calanus helgolandicus (V-VI) (Claus, 1863) & 3.88 & 0.81 & 0.11 & 2.79 & 10.57 & 2.57 & 3.24 & 9.16 & 1.35 & 23.04 & 30.55 & 5.77 \\
\hline Candacia armata (Boeck, 1872) & 0.09 & 0.02 & 0.00 & 0.33 & 1.23 & 0.38 & 0.52 & 1.46 & 0.36 & 1.15 & 1.53 & 0.22 \\
\hline Centropages chierchiae (Giesbrecht, 1889) & 0.24 & 0.05 & 0.01 & 8.86 & 33.52 & 10.45 & 4.10 & 11.59 & 1.68 & 4.74 & 6.28 & 1.42 \\
\hline Centropages typicus (Kröyer, 1849) & 8.71 & 1.81 & 0.20 & 0.07 & 0.26 & 0.15 & 0.16 & 0.46 & 0.10 & 3.79 & 5.02 & 0.92 \\
\hline Centropages spp..$^{c}$ & 1.03 & 0.21 & 0.05 & --- & --- & --- & 3.91 & 11.05 & 1.88 & --- & --- & --- \\
\hline Clausocalanus spp. & 6.54 & 1.36 & 0.22 & 0.22 & 0.84 & 0.24 & 3.73 & 10.54 & 1.38 & 11.34 & 15.04 & 1.25 \\
\hline Dytrichocorycaeus anglicus (Lubbock, 1855) & --- & --- & --- & 0.34 & 1.29 & 0.34 & 1.35 & 3.81 & 2.67 & 2.13 & 2.83 & 0.39 \\
\hline Eucalanus elongatus (Dana, 1849) & --- & --- & --- & --- & --- & --- & --- & --- & --- & 6.52 & 8.64 & 1.20 \\
\hline Metridia lucens (Boeck, 1864) & 1.10 & 0.23 & 0.04 & 0.10 & 0.39 & 0.19 & 0.56 & 1.57 & 0.33 & 0.77 & 1.03 & 0.15 \\
\hline Neocalanus gracilis (Dana, 1849) & 0.06 & 0.01 & 0.00 & --- & --- & --- & 1.25 & 3.52 & 1.51 & 0.04 & 0.05 & 0.02 \\
\hline Oithona plumifera (Baird,1843) & --- & --- & --- & 4.15 & 15.72 & 1.82 & 1.39 & 3.91 & 0.60 & 3.40 & 4.51 & 0.48 \\
\hline Oithona similis (Claus, 1866) & --- & --- & --- & 0.37 & 1.40 & 0.57 & 1.04 & 2.93 & 0.44 & 0.04 & 0.05 & 0.02 \\
\hline Oithona spp. & 2.40 & 0.50 & 0.06 & --- & --- & --- & 0.19 & 0.52 & 0.17 & --- & --- & --- \\
\hline Oncaea media (Giesbrecht, 1891) & --- & --- & --- & 3.49 & 13.20 & 2.98 & 13.36 & 37.73 & 7.80 & 0.43 & 0.57 & 0.12 \\
\hline Paracalanus parvus (Claus, 1863) & --- & --- & --- & 3.05 & 11.53 & 2.42 & 3.59 & 10.14 & 1.05 & 14.23 & 18.87 & 2.11 \\
\hline Paraeuchaeta hebes (Giesbrecht, 1888) & 0.62 & 0.13 & 0.02 & 5.49 & 20.80 & 3.29 & 4.41 & 10.68 & 2.86 & 1.57 & 2.08 & 0.28 \\
\hline Pseudocalanus elongatus (Boeck, 1865) & 4.47 & 0.93 & 0.14 & 8.14 & 30.83 & 11.57 & 5.72 & 16.14 & 2.74 & 2.44 & 3.23 & 0.80 \\
\hline Rhincalanus nasutus (Giesbrecht, 1888) & --- & --- & --- & --- & --- & --- & 2.22 & 6.27 & 5.71 & 0.08 & 0.11 & 0.05 \\
\hline Temora longicornis (Müller, 1792) & 1.52 & 0.32 & 0.05 & 6.28 & 23.76 & 6.53 & 2.82 & 7.96 & 1.08 & 2.59 & 3.44 & 0.80 \\
\hline Temora stylifera (Dana, 1849) ${ }^{\mathrm{d}}$ & 0.47 & 0.10 & 0.04 & 0.26 & 0.98 & 0.32 & 0.90 & 2.53 & 0.59 & 5.91 & 7.84 & 2.41 \\
\hline Other copepoda & 1.95 & 0.41 & 0.04 & 1.90 & 7.19 & 1.29 & 5.48 & 15.48 & 3.59 & 0.57 & 0.76 & 0.28 \\
\hline Copepod nauplii & 1.11 & 0.23 & 0.02 & 0.29 & 1.11 & 0.26 & 0.37 & 1.04 & 0.37 & 0.05 & 0.06 & 0.01 \\
\hline
\end{tabular}

${ }^{\mathrm{a}}$ Acartia spp. and A. longispina (CPRF4); includes juvenile stages (VIE3, COE2)

${ }^{\mathrm{b}}$ includes juvenile stages (VIE3)

${ }^{\mathrm{c}}$ includes juvenile stages (COE2)

dincludes juvenile stages (VIE3, COE2, SAE4) 
1 Table 3.

2 Copepod species most characteristic of each series.

3

\begin{tabular}{lrrrrrrrr}
\hline & \multicolumn{3}{c}{ CPRF4 } & \multicolumn{2}{c}{ VIE3 } & \multicolumn{2}{c}{ COE2 } & \multicolumn{1}{c}{ SAE4 } \\
\cline { 2 - 9 } species & $\mathrm{S}_{\mathrm{m}} / \mathrm{S}_{\mathrm{sd}}$ & $\% \mathrm{~S}$ & $\mathrm{~S}_{\mathrm{m}} / \mathrm{S}_{\mathrm{sd}}$ & $\% \mathrm{~S}$ & $\mathrm{~S}_{\mathrm{m}} / \mathrm{S}_{\mathrm{sd}}$ & $\% \mathrm{~S}$ & $\mathrm{~S}_{\mathrm{m}} / \mathrm{S}_{\mathrm{sd}}$ & $\% \mathrm{~S}$ \\
\hline A. clausi & 1.2 & 23.0 & 2.9 & 14.2 & 3.0 & 12.9 & 2.1 & 7.9 \\
C. helgolandicus (I-IV) & 0.7 & 7.9 & 2.5 & 12.2 & 1.8 & 7.0 & --- & --- \\
C. helgolandicus (V-VI) & 1.2 & 12.1 & --- & --- & 1.2 & 5.5 & 2.4 & 10.8 \\
Clausocalanus spp. & 0.7 & 8.9 & --- & --- & 1.6 & 7.4 & 3.8 & 12.8 \\
P. parvus & --- & --- & 3.4 & 9.3 & 3.4 & 9.0 & 5.5 & 12.9 \\
\hline
\end{tabular}

4

$5 \%$ : percent contribution of each species to total within series Bray-Curtis similarity

$6 \quad \mathrm{~S}_{\mathrm{m}} / \mathrm{S}_{\mathrm{sd}}$ : ratio between the mean and the standard deviation of similarity for each species 


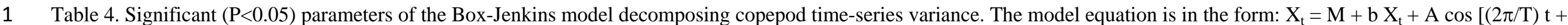
$\mathrm{P}]+\mathrm{F} \mathrm{X}_{\mathrm{t}-\mathrm{lag}}+\mathrm{R}_{\mathrm{X}}$. X: dependent variable. $\mathrm{R}_{\mathrm{X}}$ : prewhitened residuals. t: time (months). Name of series as in Table 1 .

\begin{tabular}{|c|c|c|c|c|c|c|c|c|c|c|c|c|c|c|c|}
\hline Series & period & Variable & M & $\mathrm{b}$ & $\% \mathrm{Vt}$ & $\mathrm{T}$ & A & $\mathrm{P}$ & $\% \mathrm{~V}_{\mathrm{CC}}$ & $\mathrm{F}$ & $\operatorname{lag}_{A R}$ & & $\% \mathrm{~V}_{\mathrm{AR}}$ & $\% \mathrm{~V}_{\mathrm{M}}$ & $\mathrm{n}$ \\
\hline \multirow[t]{6}{*}{ CPRF4 } & $1960-1986$ & $\mathrm{~S}$ & 8.21 & 0.17 & 15.14 & --- & --- & --- & --- & 0.32 & & 1 & 7.86 & 23.01 & 232 \\
\hline & & $\mathrm{B}$ & 24.82 & --- & --- & 12.00 & 21.07 & 3.33 & 21.08 & --- & --- & & --- & 21.08 & 232 \\
\hline & & $\mathrm{H}$ & 2.12 & 0.02 & 5.20 & --- & --- & --- & --- & --- & --- & & --- & 5.20 & 232 \\
\hline & & A. clausi & 3.96 & --- & --- & --- & --- & --- & --- & --- & --- & & --- & --- & 232 \\
\hline & & C. helgolandicus & 4.90 & --- & --- & --- & --- & --- & --- & --- & --- & & --- & --- & 232 \\
\hline & & Clausocalanus spp. & 1.46 & --- & --- & --- & --- & --- & --- & --- & --- & & --- & --- & 232 \\
\hline \multirow[t]{6}{*}{ CPRF4 } & $1997-2006$ & $\mathrm{~S}$ & 12.98 & 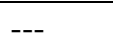 & $-\overline{---}$ & --- & $-\overline{---}$ & --- & $-\overline{---}$ & 0.27 & & 1 & 7.37 & 7.37 & 78 \\
\hline & & $\mathrm{B}$ & 12.21 & --- & --- & --- & --- & --- & --- & --- & --- & & --- & --- & 78 \\
\hline & & $\mathrm{H}$ & 2.48 & --- & --- & --- & --- & --- & --- & --- & --- & & --- & --- & 78 \\
\hline & & A. clausi & 2.36 & --- & --- & --- & --- & --- & --- & 0.30 & & 1 & 9.12 & 9.12 & 78 \\
\hline & & C. helgolandicus & 2.35 & --- & --- & --- & --- & --- & --- & --- & --- & & --- & --- & 78 \\
\hline & & Clausocalanus spp. & 0.99 & --- & --- & --- & --- & --- & --- & --- & --- & & --- & --- & 78 \\
\hline \multirow[t]{6}{*}{ VIE3 } & 1994-2006 & $\mathrm{S}$ & 14.62 & --- & --- & --- & --- & --- & --- & 0.29 & & 1 & 8.73 & 8.73 & 134 \\
\hline & & $\mathrm{B}$ & 353.98 & --- & --- & --- & --- & --- & --- & --- & --- & & --- & --- & 134 \\
\hline & & $\mathrm{H}$ & 2.70 & --- & --- & --- & --- & --- & --- & --- & --- & & --- & --- & 134 \\
\hline & & A. clausi & 79.14 & --- & --- & --- & --- & --- & --- & --- & --- & & --- & --- & 134 \\
\hline & & C. helgolandicus & 107.97 & --- & --- & --- & --- & --- & --- & --- & --- & & --- & --- & 134 \\
\hline & & Clausocalanus spp. & 0.78 & --- & --- & --- & --- & --- & --- & 0.30 & & 1 & 9.14 & 9.14 & 134 \\
\hline \multirow[t]{6}{*}{ COE2 } & 1994-2006 & $\mathrm{S}$ & 19.66 & -0.19 & 3.40 & --- & --- & --- & --- & 0.36 & & 1 & 12.24 & 15.64 & 141 \\
\hline & & $\mathrm{B}$ & 243.66 & --- & --- & 12.00 & 163.29 & 2.68 & 30.61 & --- & --- & & --- & 30.61 & 141 \\
\hline & & $\mathrm{H}$ & 2.81 & -0.02 & 2.96 & --- & --- & --- & --- & --- & --- & & --- & 2.96 & 141 \\
\hline & & A. clausi & 47.03 & --- & --- & 12.00 & 42.83 & 3.31 & 30.51 & 0.19 & & 1 & 2.63 & 33.14 & 141 \\
\hline & & C. helgolandicus & 26.78 & --- & --- & 12.00 & 25.85 & 2.83 & 23.82 & 0.37 & & 1 & 10.58 & 34.40 & 141 \\
\hline & & Clausocalanus spp. & 10.69 & -0.82 & 37.29 & --- & --- & --- & --- & --- & --- & & --- & 37.29 & 141 \\
\hline \multirow[t]{6}{*}{ SAE4 } & $1991-2001$ & $\mathrm{~S}$ & 15.35 & --- & --- & --- & $-\overline{--}$ & $\begin{array}{ll}-- \\
---\end{array}$ & $\begin{array}{l}-- \\
--\end{array}$ & 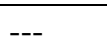 & $\begin{array}{ll}-- \\
--\end{array}$ & & 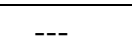 & --- & 113 \\
\hline & & $\mathrm{B}$ & 125.24 & --- & --- & 12.00 & 88.89 & 3.32 & 27.99 & --- & --- & & --- & 27.99 & 113 \\
\hline & & $\mathrm{H}$ & 2.87 & --- & --- & --- & --- & --- & --- & --- & --- & & --- & --- & 113 \\
\hline & & A. clausi & 12.29 & --- & --- & 12.00 & 15.63 & 4.12 & 33.57 & 0.27 & & 1 & 4.79 & 38.36 & 113 \\
\hline & & C. helgolandicus & 17.19 & -1.28 & 4.04 & --- & --- & --- & --- & --- & --- & & --- & 4.04 & 113 \\
\hline & & Clausocalanus spp. & 14.02 & --- & --- & --- & --- & --- & --- & --- & --- & & --- & --- & 113 \\
\hline
\end{tabular}




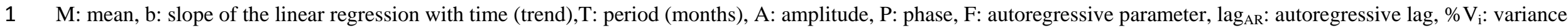
2 contribution (percent) of each component, $\% \mathrm{~V}_{\mathrm{M}}$ : total variance contribution of the model, $\mathrm{n}$ : number of data points.

3 S: copepod species number, B: copepod biomass, H: copepod diversity. 
1 Table 5. Significant $(\mathrm{P}<0.05)$ cross-correlation coefficients between environmental (env) and copepod (cop) 2 variables after removal of linear, periodic and autocorrelation components.

3

\begin{tabular}{|c|c|c|c|c|c|c|c|c|}
\hline series & period & env & cop & $\mathrm{CC}_{1}$ & $\operatorname{lag}_{1}$ & $\mathrm{CC}_{2}$ & $\operatorname{lag}_{2}$ & \\
\hline \multirow[t]{6}{*}{ CPRF4 } & 1960-1986 & $-\mathrm{v}_{\mathrm{G}}$ & $\mathrm{H}$ & -0.128 & 2 & --- & --- & \\
\hline & & $-\mathrm{v}_{\mathrm{G}}$ & B & -0.114 & 3 & --- & --- & \\
\hline & & $-\mathrm{v}_{\mathrm{G}}$ & C. helgolandicus & -0.170 & 3 & -0.114 & & 4 \\
\hline & & SST & $\mathrm{B}$ & 0.113 & 3 & --- & --- & \\
\hline & & SST & A. clausi & 0.145 & 3 & --- & --- & \\
\hline & & SST & C. helgolandicus & -0.070 & 0 & --- & --- & \\
\hline \multirow[t]{4}{*}{ CPRF4 } & 1997-2006 & $-\mathrm{u}_{\mathrm{C}}$ & A. clausi & 0.248 & 2 & --- & --- & \\
\hline & & $-\mathrm{u}_{\mathrm{C}}$ & C. helgolandicus & -0.209 & 5 & --- & --- & \\
\hline & & SST & $\mathrm{S}$ & 0.188 & 1 & --- & --- & \\
\hline & & SST & $\mathrm{H}$ & 0.197 & 1 & --- & --- & \\
\hline \multirow[t]{7}{*}{ VIE3 } & 1994-2006 & $-\mathrm{v}_{\mathrm{G}}$ & $\mathrm{S}$ & 0.204 & 3 & --- & --- & \\
\hline & & $-\mathrm{v}_{\mathrm{G}}$ & B & 0.207 & 3 & --- & --- & \\
\hline & & $-\mathrm{v}_{\mathrm{G}}$ & A. clausi & 0.173 & 3 & --- & --- & \\
\hline & & $-\mathrm{v}_{\mathrm{G}}$ & C. helgolandicus & 0.216 & 3 & --- & --- & \\
\hline & & SST & $\mathrm{H}$ & -0.190 & 1 & 0.174 & & 4 \\
\hline & & $\Delta \sigma_{t}$ & B & -0.182 & 4 & --- & --- & \\
\hline & & $\Delta \sigma_{\mathrm{t}}$ & A. clausi & -0.197 & 4 & --- & --- & \\
\hline \multirow[t]{7}{*}{ COE2 } & 1994-2006 & $-\mathrm{v}_{\mathrm{G}}$ & $\mathrm{S}$ & -0.192 & 4 & --- & --- & \\
\hline & & $-\mathrm{v}_{\mathrm{G}}$ & B & 0.221 & 2 & --- & --- & \\
\hline & & $-\mathrm{v}_{\mathrm{G}}$ & A. clausi & 0.225 & 5 & --- & --- & \\
\hline & & $-\mathrm{v}_{\mathrm{G}}$ & Clausocalanus spp. & -0.153 & 0 & --- & --- & \\
\hline & & SST & $\mathrm{S}$ & 0.198 & 2 & --- & --- & \\
\hline & & $\Delta \sigma_{t}$ & B & -0.161 & 0 & --- & --- & \\
\hline & & $\Delta \sigma_{t}$ & Clausocalanus spp. & 0.179 & 3 & --- & --- & \\
\hline \multirow[t]{7}{*}{ SAE3 } & 1991-2001 & $-\mathrm{u}_{\mathrm{C}}$ & $\mathrm{H}$ & 0.181 & 3 & --- & --- & \\
\hline & & $-\mathrm{u}_{\mathrm{C}}$ & B & 0.183 & 5 & --- & --- & \\
\hline & & SST & A. clausi & -0.193 & 4 & --- & --- & \\
\hline & & SST & C. helgolandicus & 0.195 & 0 & --- & --- & \\
\hline & & SST & Clausocalanus spp. & 0.207 & 0 & --- & --- & \\
\hline & & $\Delta \sigma_{t}$ & $\mathrm{~S}$ & 0.262 & 1 & --- & --- & \\
\hline & & $\Delta \sigma_{\mathrm{t}}$ & C. helgolandicus & 0.229 & 1 & --- & --- & \\
\hline
\end{tabular}

$\mathrm{CC}_{1}$ and $\mathrm{CC}_{2}$ : main and secondary significant cross-correlation coefficients, respectively $\operatorname{lag}_{1}$ and $\operatorname{lag}_{2}$ : lags corresponding to main and secondary cross-correlations, respectively $-\mathrm{v}_{\mathrm{G}}$ and $-\mathrm{u}_{\mathrm{C}}$ : components of upwelling-favourable winds for Galicia and Mar Cantábrico, respectively SST: sea surface temperature $\Delta \sigma_{\mathrm{t}}:$ difference in $\sigma_{\mathrm{t}}$ values between 5 and $50 \mathrm{~m}$ 


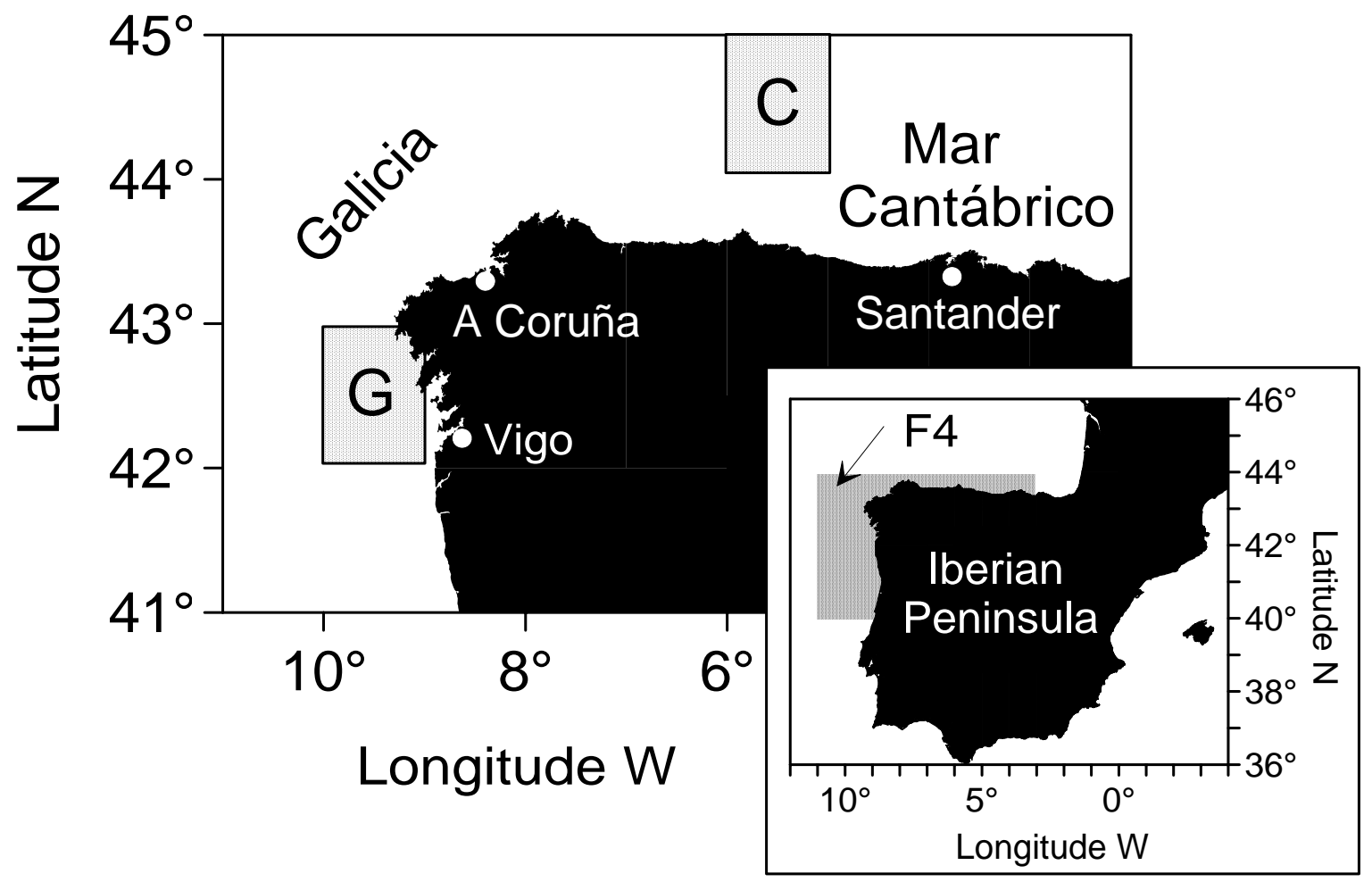

Fig. 1 


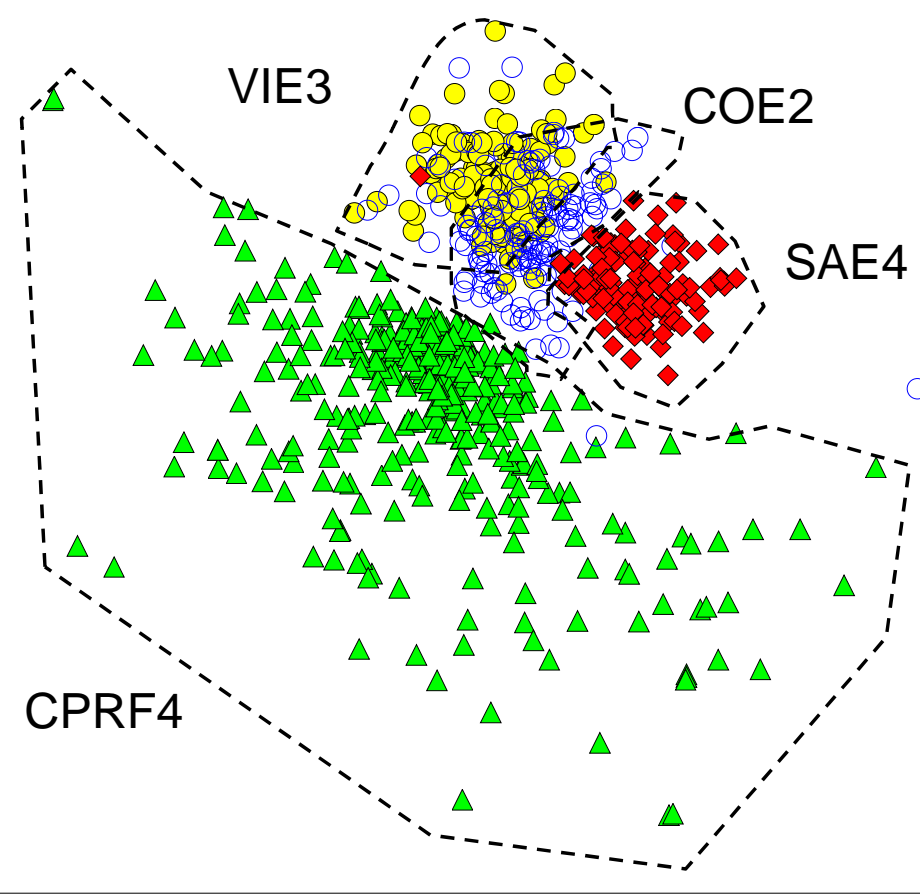

a

Stress: 0.23

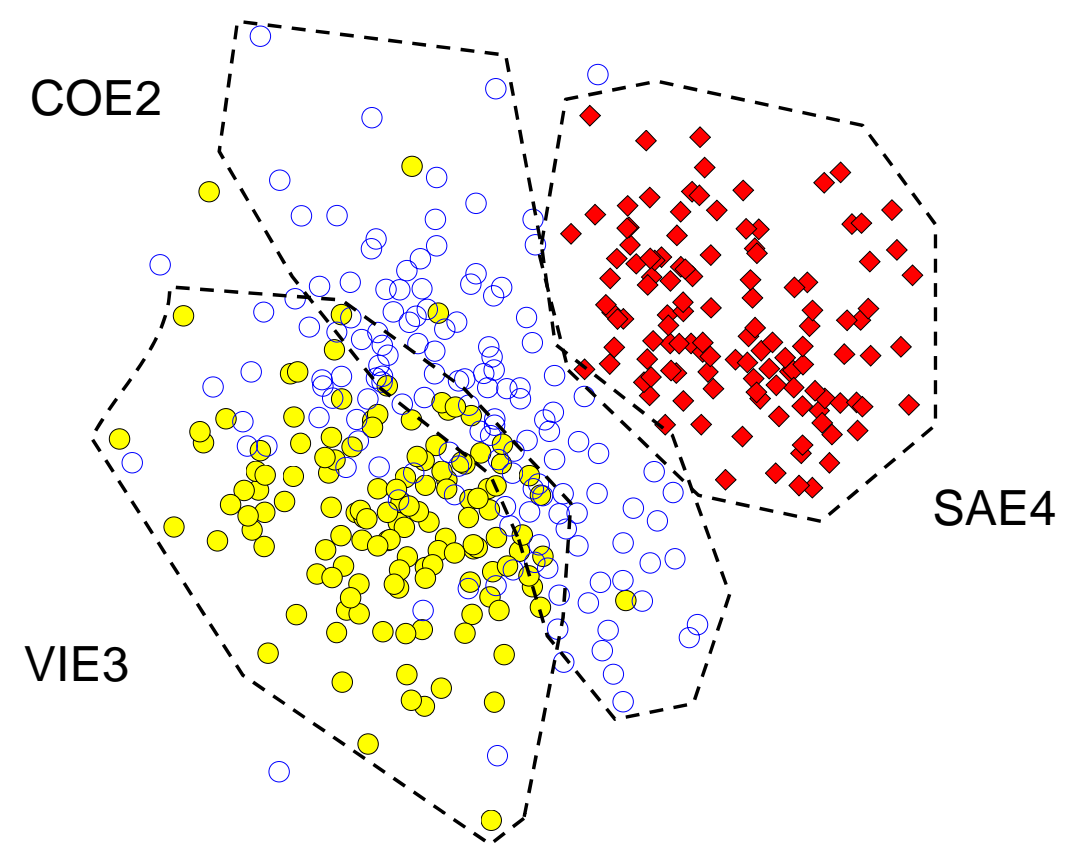

b

Fig. 2 


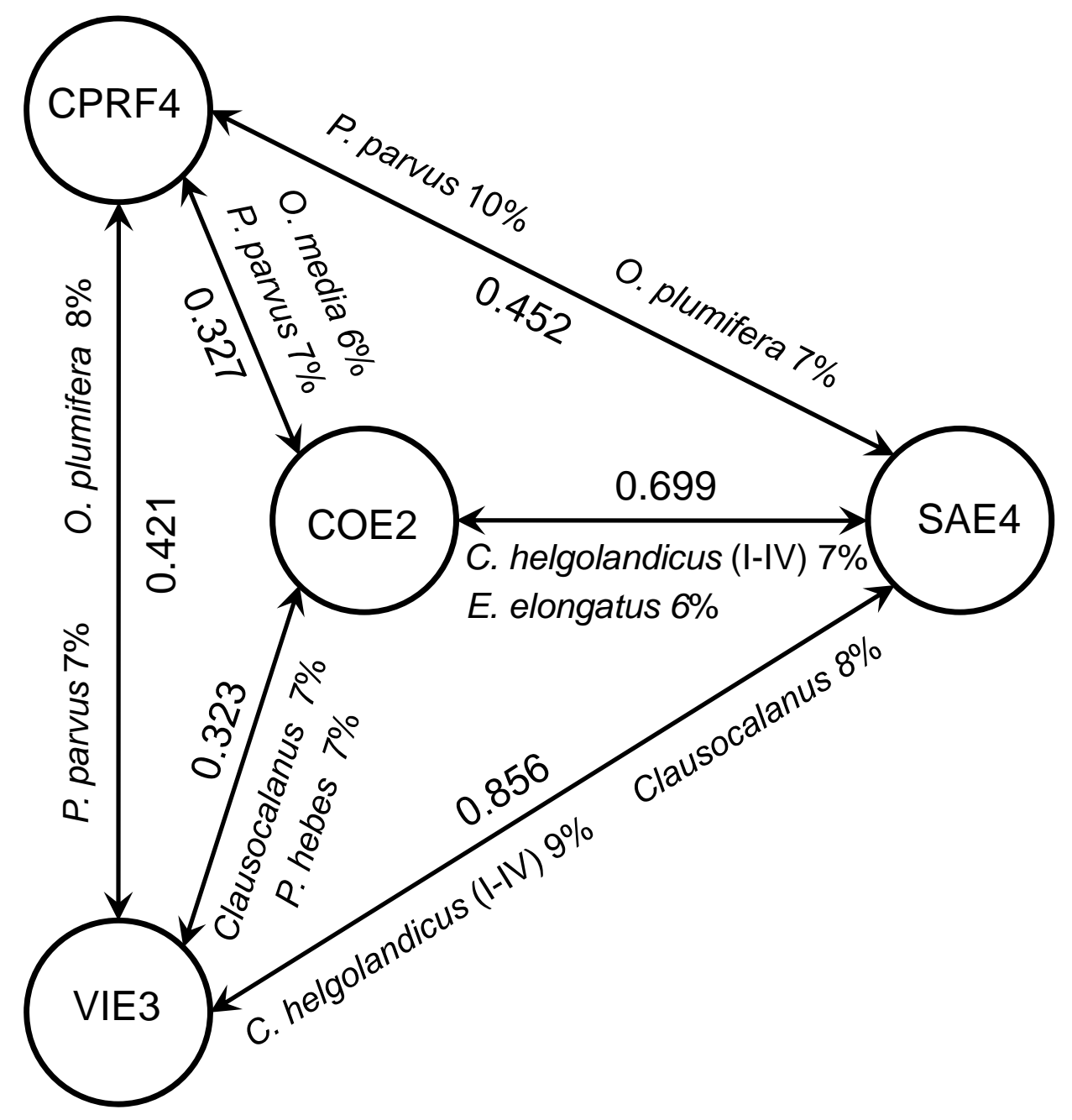

Fig. 3 

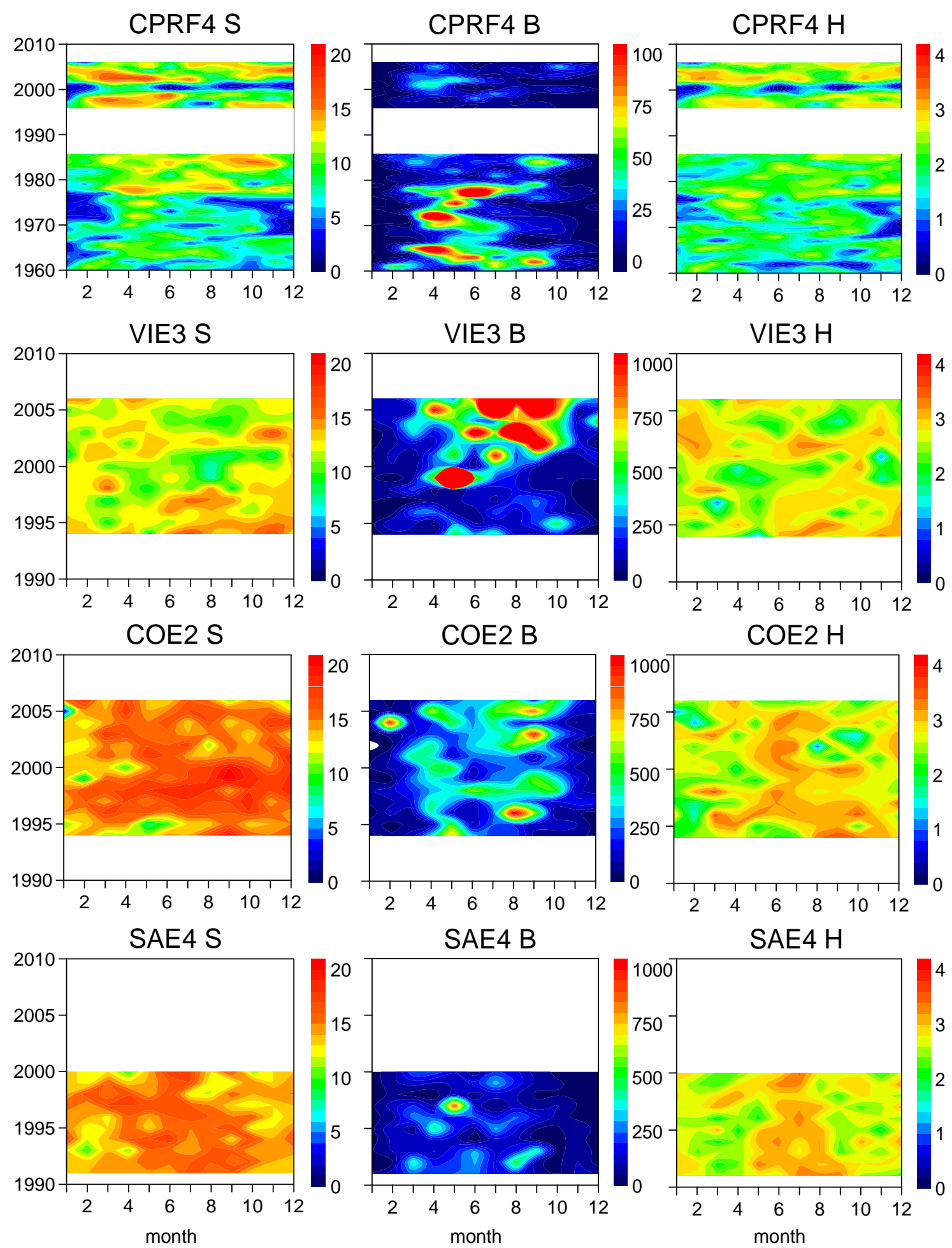

Fig. 4 

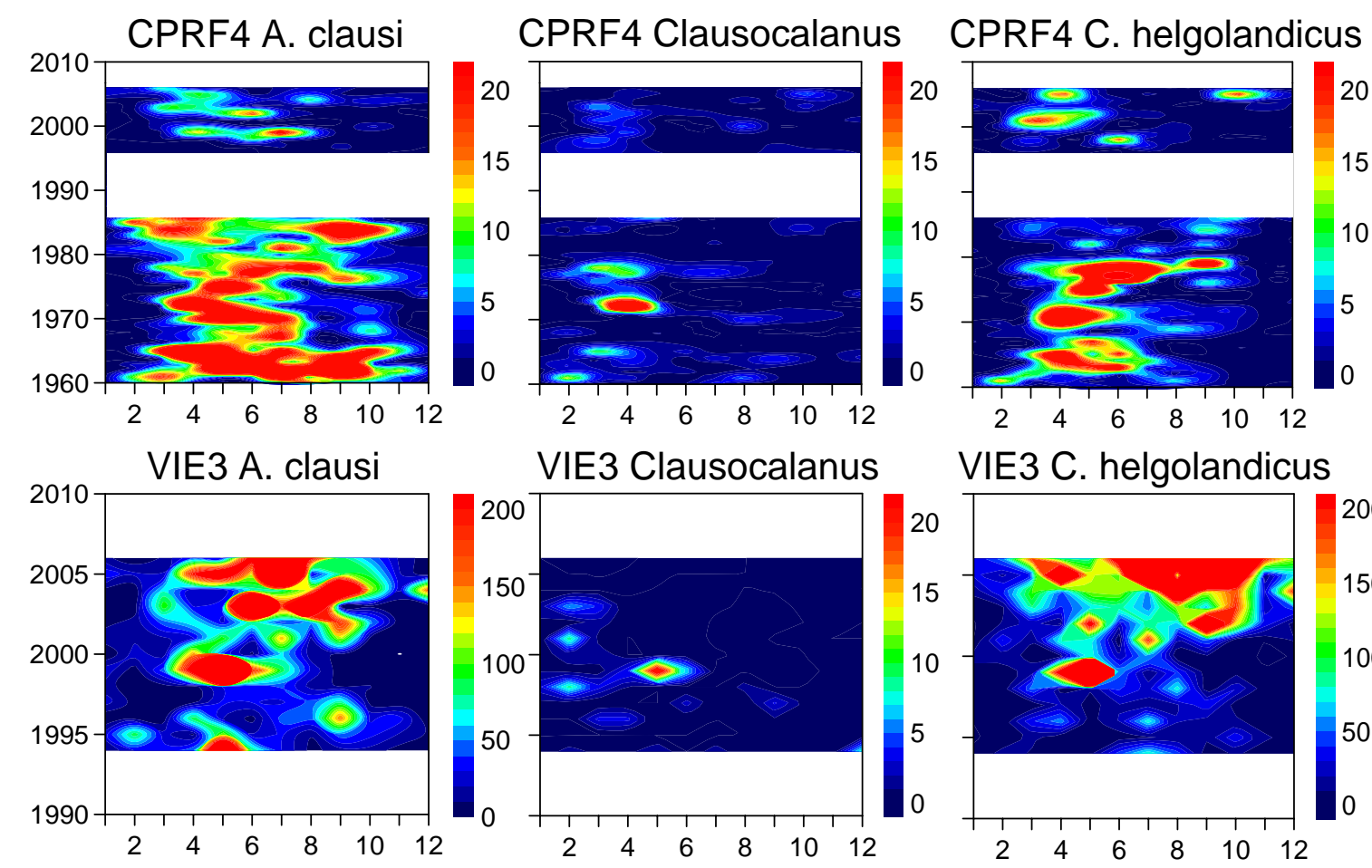

VIE3 Clausocalanus

VIE3 C. helgolandicus
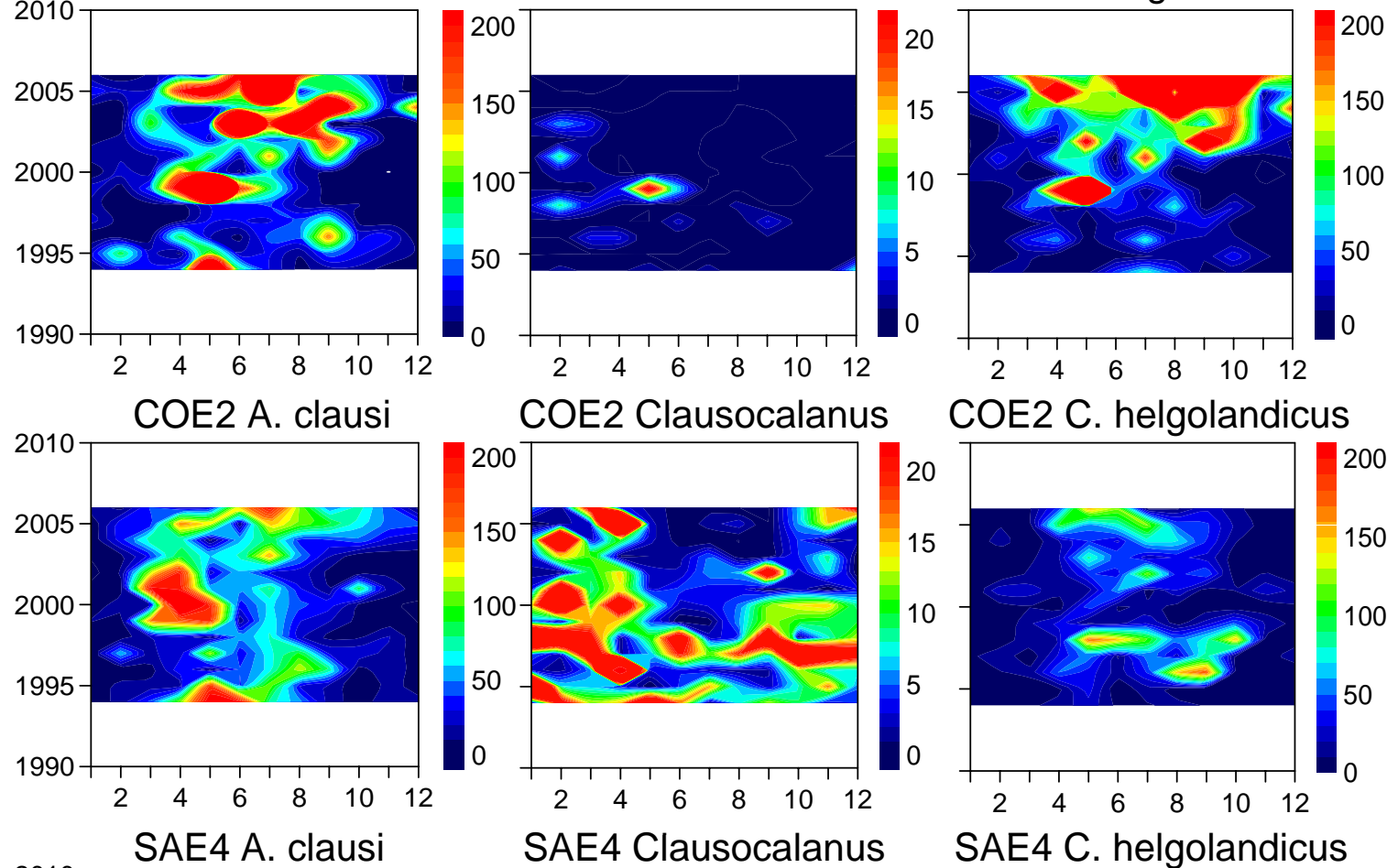

COE2 Clausocalanus

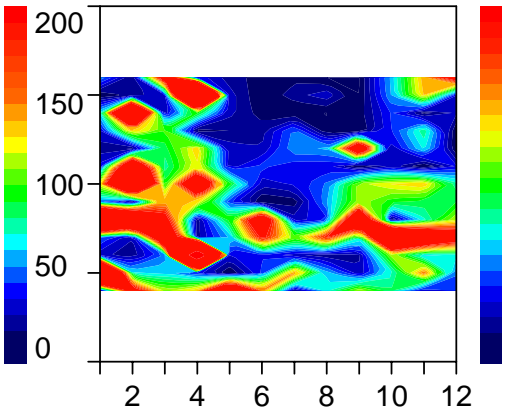

COE2 C. helgolandicus
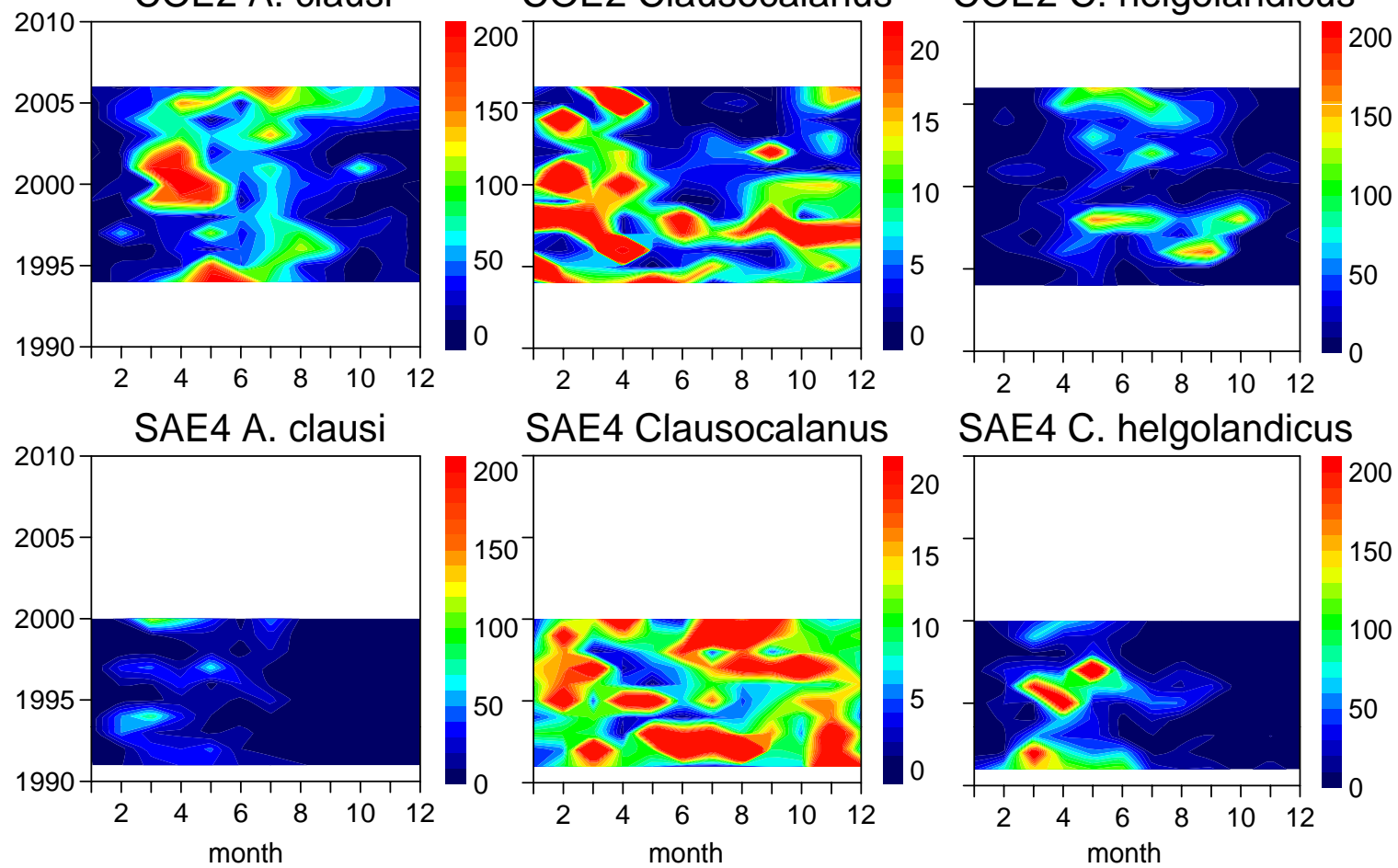

SAE4 Clausocalanus
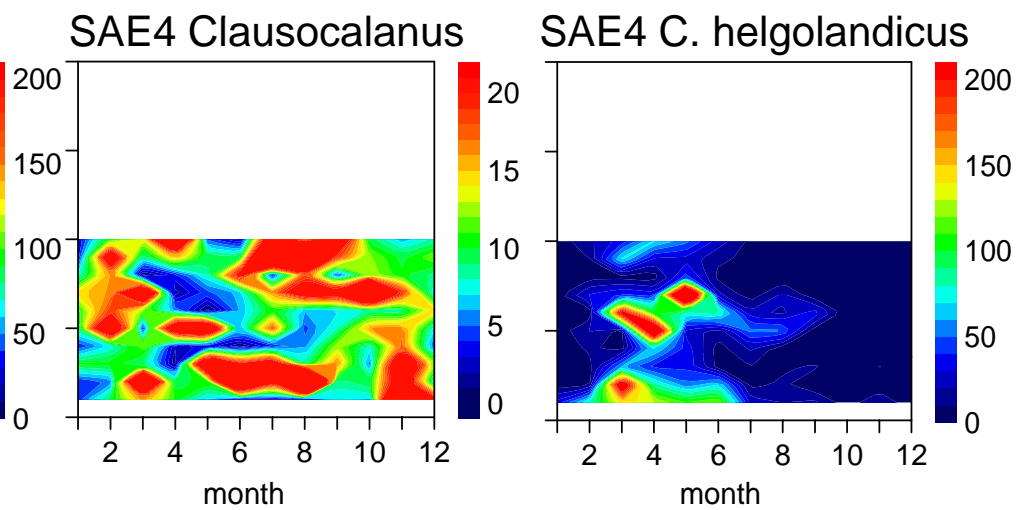

Fig. 5 

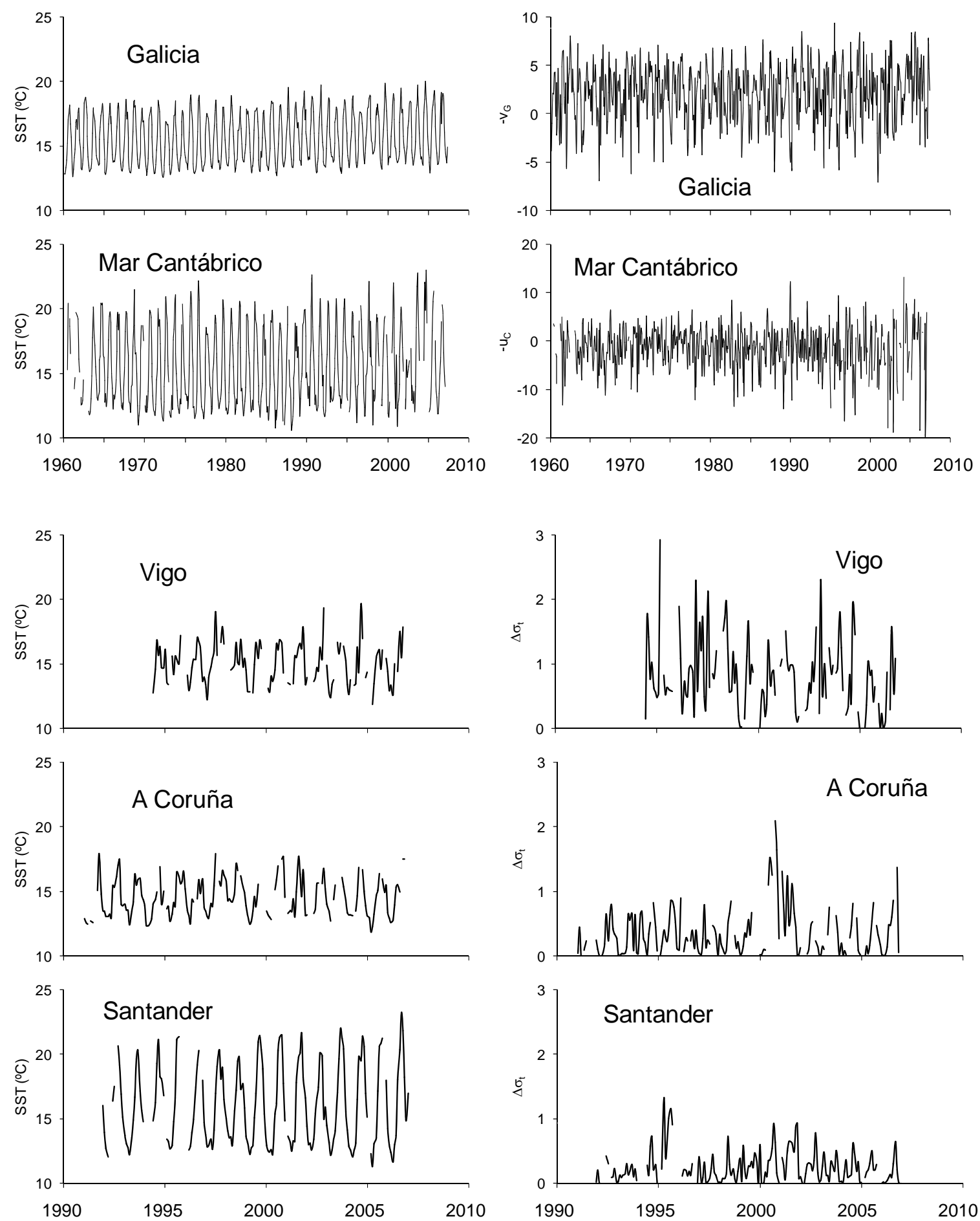

Fig. 6 